\title{
Plant Density and Irrigation Regime Have an Interactive Effect on Common Bean Seed Quality
}

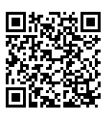

\author{
Nokuthula Cherry Hlanga and Albert Thembinkosi Modi* \\ Department of Crop Science, University of KwaZulu-Natal, South Africa
}

Submission: June 19, 2018; Published: July 26, 2018

*Corresponding author: Albert Thembinkosi Modi, Department of Crop Science, School of Agricultural, Earth and Environmental Sciences, University of KwaZulu-Natal, P/Bag X01, Scottsville, 3209, South Africa Email: modiat@ukzn.ac.za

\begin{abstract}
Dry beans (Phaseolus vulgaris L.) are known to be a significant source of protein, fibre, vitamins, and minerals. However, poor access to improved quality seeds, water stress and poor agronomic practices have led to low productivity for smallholder farmers in South Africa. The study used three certified dry bean seed cultivars (Mtata, Malelani, and Gadra). A standard germination test, water activity and seed moisture content were determined each replicated three times. Pre and post-harvest germination tests were conducted simultaneously with Germination Velocity Index (GVI) and Mean Germination Time (MGT). A field trial was designed as a split plot where rain-fed and irrigation treatments were the main plots within which the three cultivars were planted at three densities (low, medium and high). Seed quality of the certified seed lot showed a significant difference between cultivars. Mtata had an average of 93\% germination, while Malelani and Gadra had $82 \%$ each. There were significant differences between cultivars with respect to germination after harvest. Germination Velocity Index showed that there was a significant difference $(\mathrm{P}<0.05)$ for the interaction of water regime $\mathrm{x}$ density $\mathrm{x}$ cultivar. Across all densities and for all cultivars GVI was higher under irrigation compared with dry land conditions. It is concluded that water availability and plant density have interactive effects on dry bean seed quality.
\end{abstract}

Keywords: Germination; Plant density; Seed quality; Water regime

Abbreviations: GVI: Germination Velocity Index; MGT: Mean Germination Time

\section{Introduction}

Common beans are an important source of essential vitamins, minerals; and most importantly, proteins [1]. Deficiency in humans has led to protein-deficient diseases such as muscle wasting, swelling due to water retention, low blood pressure and heart rate, anaemia and liver problems [2]. Dry beans (Phaseolus vulgaris) are known to be a significant source of protein, fibre, vitamins, and minerals [3]. However, access to improved agricultural resources such as quality seeds and water stress has been observed to be a limiting factor to productivity in developing countries [4]. Smallholder farmers have been observed to use retained dry bean seed harvested from previous seasons as they cannot afford to purchase improved seed varieties [5]. Due to the self-pollinating nature of legumes, inbreeding depression often leads to decreased quality and vigour of subsequent seed [6]. In addition, water stress conditions in which the maternal plant is exposed affects seed quality and vigour [7]. Therefore, the use of retained seed coupled with areas of limited water availability increases the risk of low and non-uniform germination and poor seedling emergence leading to significant yield losses [7].
The use of retained dry bean seed combined with limited resources and knowledge for agricultural production will continue to dominate many smallholder farmers. Water stress on developing maternal plant has been observed to affect seed mass and endosperm biochemical constituents; thus affecting seed quality (soybean and faba beans) [8], and vigour [9]. Ahmadi and Bahrani [10] observed that water stress on sunflower under water limited conditions resulted in poor seed set, small and shrivelled seed; this was strongly correlated to subsequent reduction in seed quality. On the contrary, other authors have reported no significant effect on seed quality in response to production environment [11-13]. Opportunities for improving dry bean seed quality exist in the use of good water management strategies on the maternal plant. Such strategies include the use of appropriate planting dates, plant densities and adaptable varieties. Planting dry bean at an appropriate planting date resulted in increased crop growth period, and pod number, number of grains per pod, 100-grain weight, and finally grain yield [14]; this also translated to high progeny seed quality. A study done by Joshi \& Rahevar [15] showed 
that optimum plant spacing improved water use efficiency and consequently improved seed quality. Ghassemi-Golezani \& Mazloomi-Oskooyi [6] reported that the use of drought tolerant varieties increased seed quality of dry bean.

Although the use of optimum agronomic management practices can be used to improve subsequent dry bean seed quality under water-limited conditions, there is gap in information to quantify the possible gains. In-order to ensure that smallholder farmers sustainably produce dry beans, there is a need to assess and quantify the effects of different agronomic practices on subsequent seed quality. Therefore, the aim of this study was to determine the effect of planting date, plant density and water availability on subsequent seed quality of different dry bean varieties. The specific objectives were to determine initial, and subsequent seed quality for three bean varieties grown under varying agronomic practices.

\section{Materials and methods}

\section{Plant material}

Three dry bean varieties, namely, Mtata, Malelani, and Gadra, were sourced from McDonald's Seeds (Pty) Ltd in Pietermaritzburg KwaZulu-Natal. Umtata is a determinate variety reported to be suitable for growing under conditions prevalent around Pietermaritzburg. Malelani is a fine bean for the pre-pack market bred to suit South African conditions. Malelani yields a very attractive straight bean, with a green colour, and with an excellent uniformity. The field holding ability of Malelani is good while seed development is slow. It has good disease resistance and vigorous growth. Gadra is well adapted to the lowveld and KwaZulu-Natal production areas and well adapted for late planting when compared with other varieties. It is early maturing, excellent disease resistance, upright, bush growth habit and large seed size.

\section{Seed quality test}

A series of seed quality tests were conducted for the original purchased seeds and the progeny at the University of KwaZulu-Natal's seed technology laboratory. For the progeny, seed quality tests also included water activity and seed moisture content.

\section{Water activity and seed moisture content}

The Decagon Model AquaLab Series 3 water activity meter (Decagon Devices, USA) was used to measure seed water activity. Three replications were done for each treatment. A grain moisture meter (Model am-5000, China) was used to measure seed moisture content of harvested seeds using settings (P8) for dry bean. Three replications were also done for each treatment.

\section{Standard germination test}

Seed germination capacity was determined using the standard germination test under laboratory conditions.
Briefly, three replicates consisting of 25 seeds of each variety (Gadra, Mtata and Malelani) were germinated between doublelayered moistened brown paper towels (ISTA, 2011). The paper towels were rolled and tied at either end with rubber bands before being placed in zip-lock bags to prevent moisture loss. The zip-lock bags were then placed in a germination chamber set at $25^{\circ} \mathrm{C}$ (Germination cabinets, Model PL2, England) were they were kept for 8 days. Seed germination was observed daily, and germination was defined as radicle protrusion of 2 mm (ISTA, 2011).

\section{Germination velocity index}

Seed vigour was measured using the germination velocity index (GVI) (germination speed) and calculated based on Maguire's (1962) formula:

$$
G V I=G 1 / N 1+G 2 / N 2+\ldots+G n / N n
$$

where:

$G V I=$ Germination Velocity Index,

$G 1, G 2 \ldots G n=$ number of germinated seeds in first, second $\ldots$ last count, and

$N 1, N 2 \ldots N n=$ number of sowing days at the first, second $\ldots$ last count.

\section{Mean germination time}

Mean germination time (MGT) was calculated according to Ellis and Roberts (1981) formula:

$$
M G T=\sum \mathrm{Dn} / \sum \mathrm{n}
$$

where;

$\mathrm{n}=$ number of seeds which were germinated per day D, and

$\mathrm{D}=$ number of days counted from the beginning of germination.

\section{Field trials}

A set of trials were conducted to determine the effect of planting date, plant density and water availability on dry bean growth, development and yield over two seasons (early and late season).

\section{Description of experimental site and management}

Field trials were conducted at the University of KwaZuluNatal's Ukulinga Research Farm in Pietermaritzburg (29 $37^{\prime}$ S; $30^{\circ} 16^{\prime} \mathrm{E} ; 775 \mathrm{~m}$ a. s. l.). The planting dates for the early and late season were 12 January and 03 May 2016, respectively. The trials were harvested on 12 April and 13 September 2016, respectively.

Prior to planting, soil samples were taken from the field for soil fertility analyses. The sampling followed standard sampling procedure of taking three samples randomly in the 
field from upper, middle, and lower part of the field to represent the whole field. Soil samples were analysed for soil fertility at Cedara (29 31' 59.99" S and Longitude: $30^{\circ} 16^{\prime} 60.00^{\prime \prime} \mathrm{E}$ ). The same procedure was repeated again after harvesting to determine soil fertility levels at the end of the season.

\section{Experimental design}

The experimental design was a split-plot laid out in randomised complete blocks and replicated three times. There were three factors, namely, (i) varieties (Mtata, Malelani and Gadra), (ii) plant densities (high, medium and low), and (iii) water regime (rain-fed and irrigated). The field was 30 x $20 \mathrm{~m}$. The three varieties were as described in Section 3.1. High plant density involved planting seeds at $0.5 \times 0.2 \mathrm{~m}$, low medium density at $0.5 \times 0.3 \mathrm{~m}$ and high density at $0.5 \times 0.5 \mathrm{~m}$. The irrigated water regime included watering the crops at 30 mm per week for the duration of the trials. Rain-fed trials were established with irrigation to allow for maximum plant stand thereafter, irrigation was withdrawn after crop establishment.

Prior to land preparation, soil samples were taken to Cedara for analysis and fertility recommendations. Land preparation was done by disking and rotovating to achieve a fine tilth. The field trials were sprayed using Mancozeb (Dithane M45) at $45 \mathrm{~g} / 15 \mathrm{~L}$ for cutworm. Weeding was done routinely by hand hoeing.

\section{Statistical analysis}

Data collected were subjected to analyses of variance (ANOVA) using GenStat ${ }^{\circledR}$ Version 18 (VSN International, United Kingdom) at the 5\% probability level. Duncan's test on GenStat $®$ at the probability level of $5 \%$ was used to compare means.

\section{Results and Discussion}

There were significant differences $(\mathrm{P}=0.027)$ observed for final germination for three dry bean varieties. Although these differences were nominal, the trend observed the for final germination was Mtata (91.5\%) > Gadra (84.5\%) > Malelani (83.5\%) (Figure 1).

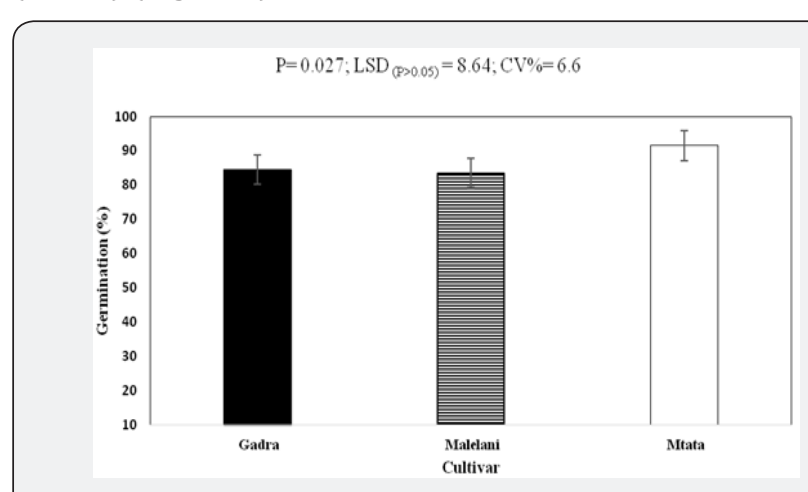

Figure 1: A comparison of final germination percentage for three dry bean varieties (Mtata, Gadra and Malelani). Standard error bar represent standard deviation $( \pm 4.32)$.
There were significant differences $(\mathrm{P}=0.027)$ observed for Germination Velocity Index (GVI) for three dry bean varieties. The trend for germination velocity index was Mtata (24) > Gadra (23.1) > Malelani (21.9) (Figure 2).

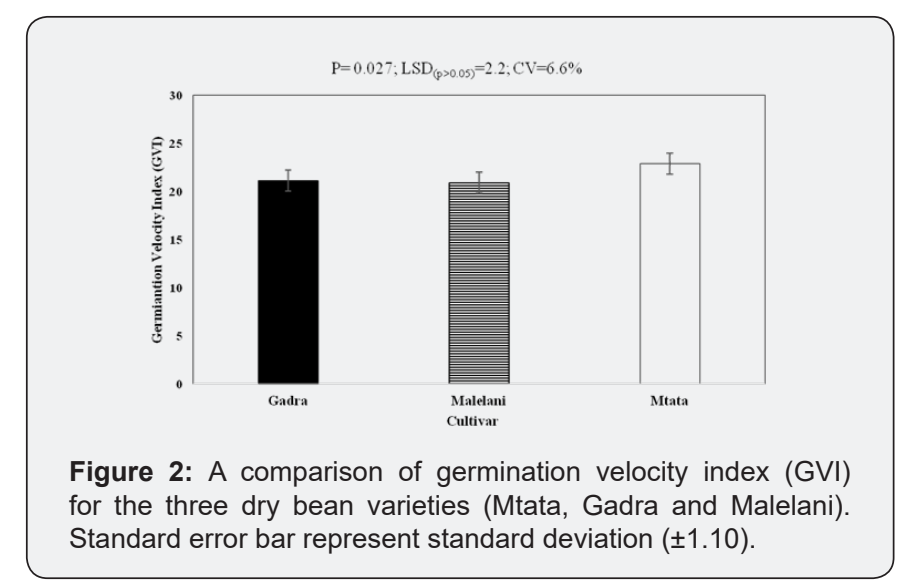

There was a significant difference $(\mathrm{P}<0.05)$ for germination percentage with regards to the interactions of water regime $x$ plant density $\mathrm{x}$ variety $\mathrm{x}$ time interaction. Overall, across the water regimes and plant densities (Figure 3A- F), Gadra had the lowest germination $(28.30 \%)$ and Malelani the highest germination (98.80\%). Similarly, under the two water regimes irrigated (Figure 3A-C) and rain-fed (Figure 3D-F), Malelani had the highest germination (98.80\%) and Gadra the lowest germination percentage (31.70\%). Medium density (Figure 3B \& E) had the highest germination \% (93.20\%) while high density (Figure $3 \mathrm{C} \& \mathrm{~F}$ ) had the lowest germination percentage (74.30\%). With respect to variety Mtata and Malelani showed the highest seed germination (88.50\%) while Gadra showed the lowest germination (78.70\%).

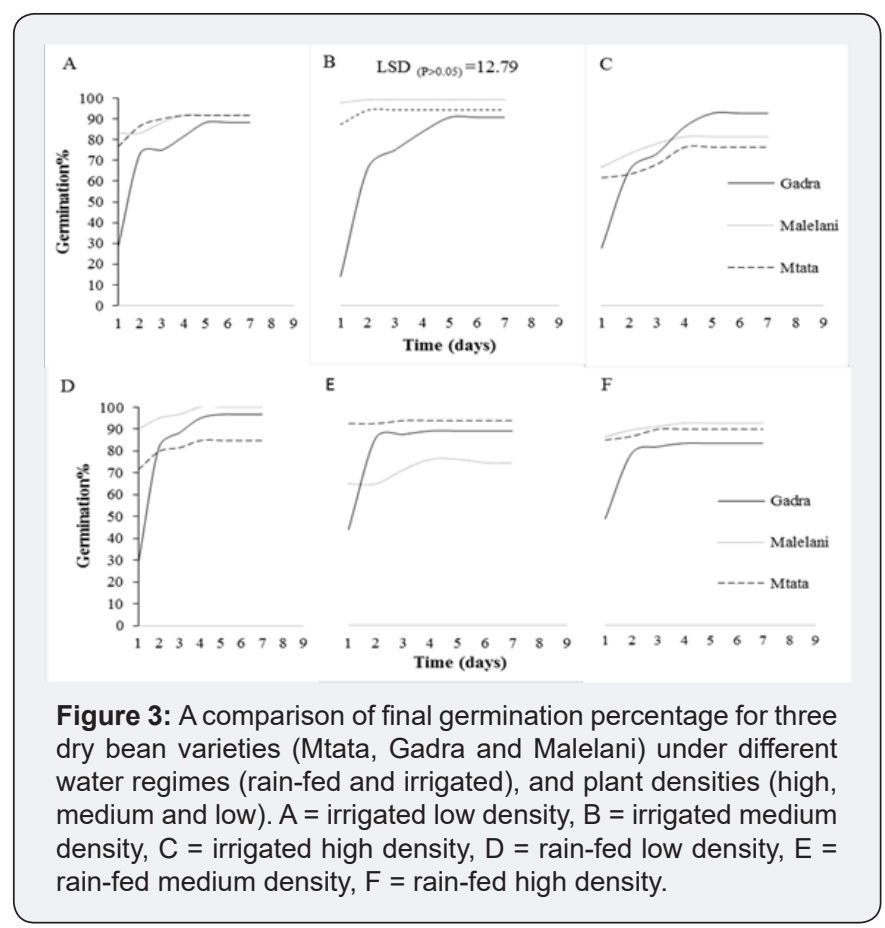


Germination Velocity Index (GVI) showed that there was a significant difference $(\mathrm{P}<0.05)$ for the interaction of water regime $\mathrm{x}$ plant density $\mathrm{x}$ variety (Figure 4). Overall, the mean GVI for the dry bean varieties were 2.57, 2.47 and 2.57 for Malelani, Mtata and Gadra respectively (Figure 3 \& 4). Germination Velocity Index showed that seeds harvested from maternal plants grown under irrigated conditions had higher GVI compared to under rain-fed conditions. Medium planting density had the highest GVI (3.56) relative to low planting density (2.51) and high planting density (2.19).

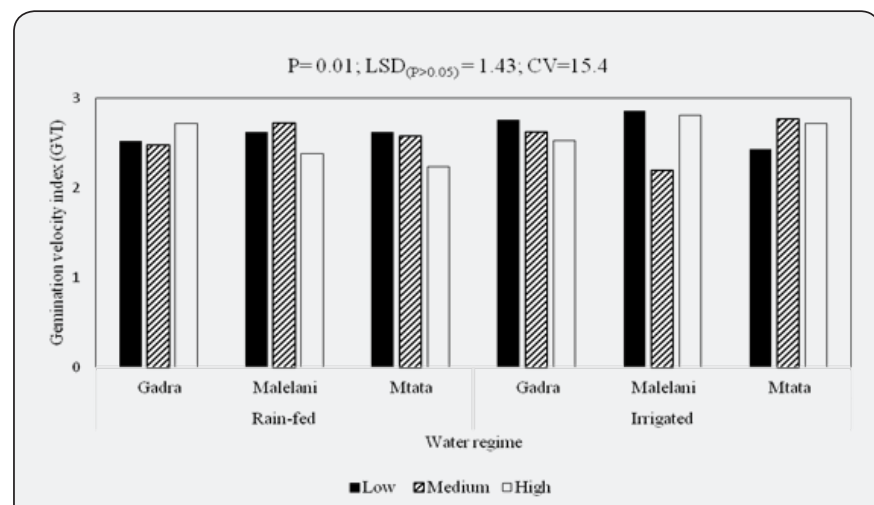

Figure 4: A comparison of Germination Velocity Index (GVI) for three dry bean varieties (Mtata, Gadra and Malelani), under different water regimes (rain-fed and irrigated), and plant densities (high, medium and low). Standard error bar represent standard deviation $( \pm 0.71)$.

There were significant differences $(\mathrm{P}=0.01)$ observed for the Mean Germination Time (MGT) for the interaction of water regime x plant density x variety. Gadra had the lowest MGT respectively to Mtata and Malelani, Malelani (0.44 days) $>$ Mtata (0.42 days) > Gadra (0.36 days). Under irrigation, MGT was lower ( 0.35 days) relative to when dry beans were grown under rain-fed conditions (0.39 days). For three plant densities MGT was observed to be higher under high density (high density (0.42 days) $>$, medium density (0.4 days) $>$, and low density (0.38 days). Across all treatment combinations, Malelani under irrigation, and medium density had the highest MGT, and the lowest MGT was seen for Malelani under low density under irrigated conditions (Figure 5).

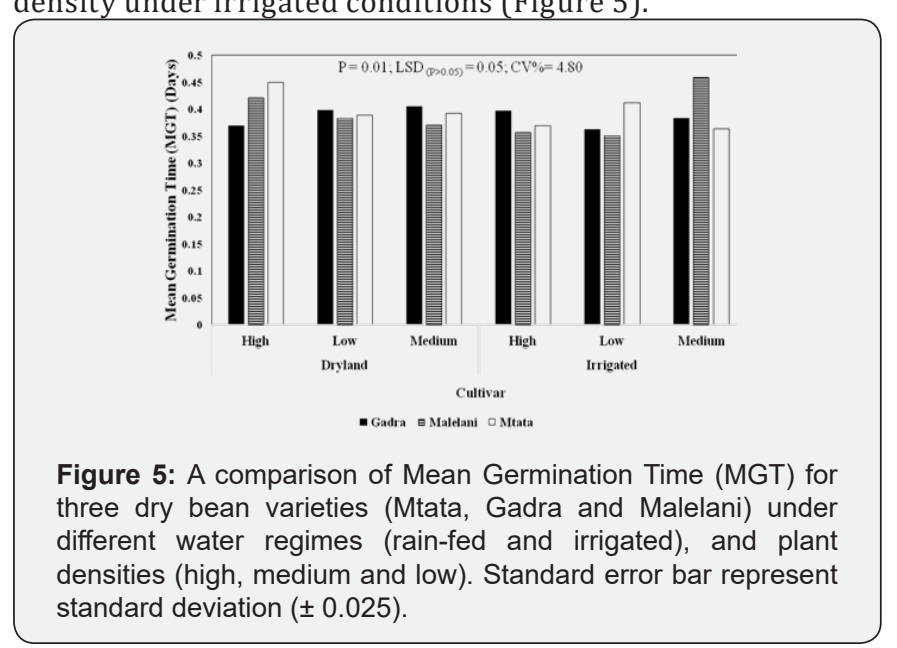

An interaction of plant density and cultivar had significant effect $(\mathrm{P}=0.041)$ on dry bean seed moisture content. Planted under the low-density treatment had the lowest seed moisture content $(9.90 \%)$ relative to high $(10.10 \%)$ and medium $(10.20 \%)$. There was no significant difference $(\mathrm{P}>0.05)$ between the three dry bean varieties Gadra (10.00\%), Malelani (10.10\%), and Mtata (10.00\%). The treatment combination of variety (Malelani) and medium plant density had the highest seed moisture content compared to the low and high plant densities. Overall Mtata variety under high plant density showed highest grain moisture (Figure 6).

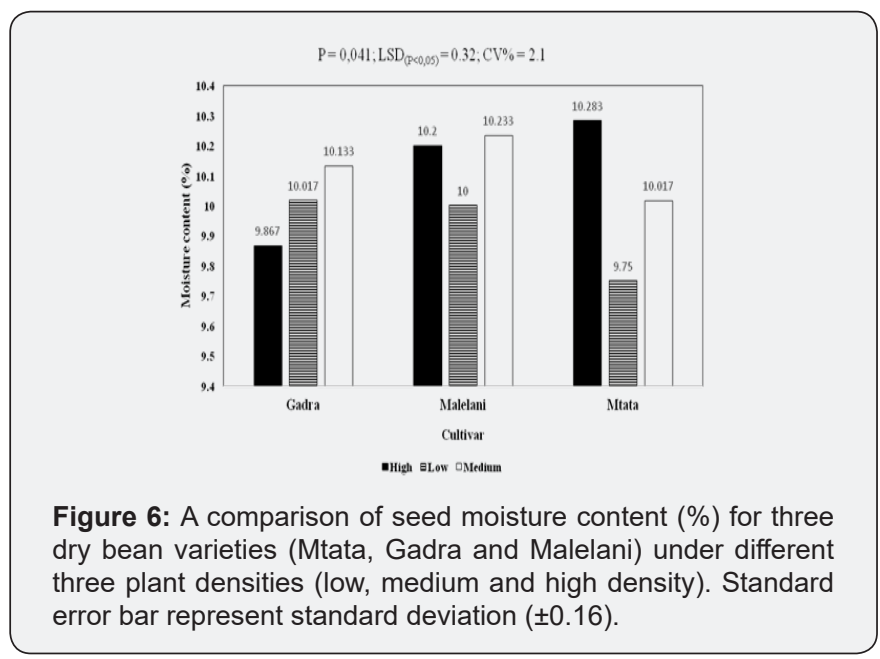

There were highly significant differences $(\mathrm{P}=0.001)$ observed for the seed water activity for the interaction of water regime x variety (Appendix G). Seeds harvested from maternal plants grown under irrigated conditions had the lowest water activity (0.52) when compared with rain fed field (0.54) (Figure 7 ). The treatment combination of variety $x$ water regime, seeds of Mtata harvested under rain-fed conditions had the highest water activity relative to irrigated field. While Gadra under irrigated conditions had the lowest water activity (Figure 7).

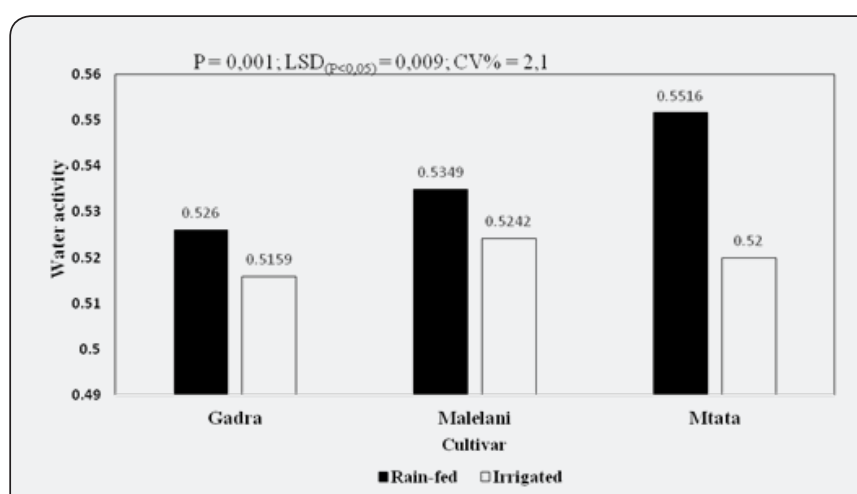

Figure 7: A comparison of water activity for three dry bean varieties (Mtata, Gadra and Malelani) under different two water regimes (rain-fed and irrigated). Standard error bar represent standard deviation $( \pm 0.0045)$.

Significant differences $(\mathrm{P}<0.05)$ were observed under pre-planting and post planting germination results among the dry bean seeds varieties. This confirms that studied dry 
bean seed varieties had an influence on the subsequent seed quality. This could because of the genetic differences amongst the dry bean seed varieties [16]. Initially, Mtata variety had the highest percentage seed germination but Malelani had the highest percentage germination post-planting. This shows that subsequent dry bean seed quality was affected environmental factors due to maternal plant [17].

Seeds produced under rain-fed conditions had high germination percentage over a short period. Germination velocity index was higher under rain-fed conditions when compared with under irrigated conditions. Mean germination time was lower under rain-fed conditions meaning that the subsequent seeds were able to germinate faster than those from the irrigated trial. This could suggest that limited water availability subsequent seed quality could actually be enhanced [10]. Under water limited conditions, adaptable seed will aim to germinate and establish quickly to take advantage of available water [6]. It could be that the reduction in pod number and average seed number per pod under water stress conditions helps maintain seed integrity with regards to seed quality [13]. It was observed also that under the lower plant densities the seed quality indices were low. This implies that planting dry bean under low plant density has no favourable gain on seed quality but only on grain yield.

\section{Conclusion}

In the present study, subsequent dry bean seed quality varied among different management practices. Mtata, Malelani and Gadra dry bean varieties varied in their responses to the varied agronomic conditions. Seed germination, GVI, and MGT were favourable under rain-fed conditions. This implies that dry bean seed can be grown under rainfed conditions for the purposes of seed without adverse effects on the quality (germination and vigour) of the seed. The study also highlights the importance of the correct combination of management practices in which the maternal plants are exposed for good quality seeds.

\section{Acknowledgement}

The Water Research Commission of South Africa is acknowledged for funding this research through WRC Project No. K5 /2274//4 "Determining water use of indigenous grain and legume food crops". The Agricultural Research Council of South Africa is also acknowledged.

\section{References}

1. Kruger HS, Steyn NP, Swart EC, Maunder EM, Nel JH, et al. (2012) Overweight among children decreased, but obesity prevalence remained high among women in South Africa, 1999-2005. Public Health Nutr 15(4): 594-599.
2. Munro HN (2012) Mammalian protein metabolism. Academic press publishers, New York and London, Volume IV: 23-30.

3. Wani IA, Sogi DS, Shivhare US, Gill BS (2015) Physico-chemical and functional properties of native and hydrolyzed kidney bean (Phaseolus vulgaris $L$.) protein isolates. Food Research International 76:11-18.

4. Lee J, Gereffi G, Beauvais J (2012) Global value chains and agri food standards: challenges and possibilities for smallholders in developing countries. Proc Natl Acad Sci USA 109(31): 12326-12331.

5. Azadi H, Samiee A, Mahmoudi H, Jouzi Z, Rafiaani Khachak P, et al. (2016) Genetically modified crops and small-scale farmers: main opportunities and challenges. Crit Rev Biotechnol 36(3): 434-446.

6. Ghassemi-Golezani K, Mazloomi-Oskooyi R (2012) Effect of water supply on seed quality development in common bean (Phaseolus vulgaris var.). International Journal of Plant Production 2(2): 117-124.

7. Müller M, Siles L, Cela J, Munné-Bosch S (2014) Perennially young: seed production and quality in controlled and natural populations of Cistus albidus reveal compensatory mechanisms that prevent senescence in terms of seed yield and viability. J Exp Bot 65(1): 287-297.

8. Trivedi M (2013) Biofield and fungicide seed treatment influences on soybean productivity, seed quality and weed community. Agricultural Journal 138-143.

9. Ghassemi-Golezani K, Hosseinzadeh-Mahootchy A (2009) Changes in seed vigour of faba bean (Vicia faba $L$.) varieties during development and maturity. Seed Science and Technology 37(3): 713-720.

10. Ahmadi M, Bahrani M (2009) Yield and yield components of rapeseed as influenced by water stress at different growth stages and nitrogen levels. American-Eurasian Journal of Agricultural and Environmental Sciences 5(6): 755-761.

11. Ahmad S, Ahmad R, Ashraf MY, Ashraf M, Waraich EA (2009) Sunflower (Helianthus annuus $L$.) response to drought stress at germination and seedling growth stages. Pakistan J Bot 41(2): 647-654.

12. Kheira AAA, Atta NM (2009) Response of Jatropha curcas L. to water deficits: Yield, water use efficiency and oilseed characteristics. Biomass and Bioenergy 33(10): 1343-1350.

13. Odindo AO (2010) Cowpea seed quality in response to production site and water stress. Doctoral dissertation, University of KwaZulu-Natal p. 45-56.

14. Mirzaienasab M, Mojaddam M (2014) The effect of planting date on yield and yield components of two red bean cultivars in Azna weather conditions. Indian Journal of Fundamental and Applied Life Sciences 4(3): 417-422.

15. Joshi S, Rahevar H (2014) Effect of dates of sowing, row spacings and varieties on growth attributing characters of rabi Indian bean (Dolichos lablab L.). Trends in Biosciences 7: 3717-3721.

16. Elballa M, El-Amin A, Elamin E, Elsheikh EA (2015) Interactive effects of varieties, foliar application of micronutrients and rhizobium inoculation on snap bean (Phaseolus vulgaris L.) performance. Journal of Agricultural and Environmental Sciences 50: 555-612.

17. Akibode S, Maredia MK (2012) Global and regional trends in production, trade and consumption of food legume crops, Department of Agricultural, Food, and Resource Economics, Michigan State University, USA. 
This work is licensed under Creative Commons Attribution 4.0 License

DOI: 10.19080/TTSR.2018.02.555595
Your next submission with Juniper Publishers will reach you the below assets

- Quality Editorial service

- Swift Peer Review

- Reprints availability

- E-prints Service

- Manuscript Podcast for convenient understanding

- Global attainment for your research

- Manuscript accessibility in different formats

( Pdf, E-pub, Full Text, Audio)

- Unceasing customer service

Track the below URL for one-step submission https://juniperpublishers.com/online-submission.php 